WellBeing International

WBI Studies Repository

1986

\title{
Providing Humane Stewardship for Wildlife: The Case Against Sport Hunting
}

John W. Grandy

The Humane Society of the United States

Follow this and additional works at: https://www.wellbeingintlstudiesrepository.org/acwp_hmap

Part of the Animal Studies Commons, Other Anthropology Commons, and the Tourism and Travel Commons

\section{Recommended Citation}

Grandy, J.W. (1986). Providing humane stewardship for wildlife: The case against sport hunting. In M.W. Fox \& L.D. Mickley (Eds.), Advances in animal welfare science 1986/87 (pp. 295-300). Washington, DC: The Humane Society of the United States.

This material is brought to you for free and open access by WellBeing International. It has been accepted for inclusion by an authorized administrator of the WBI Studies Repository. For more information, please contact wbisr-info@wellbeingintl.org.

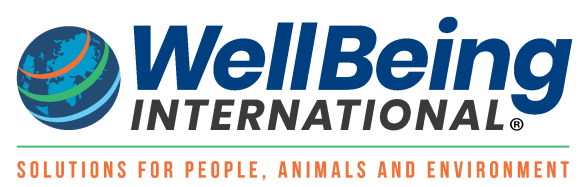




\title{
PROVIDING HUMANE STEWARDSHIP FOR WILDLIFE: THE CASE AGAINST SPORT HUNTHNG ${ }^{1}$
}

\author{
John W. Grandy ${ }^{2}$
}

It is a pleasure for me to be here today to address this important symposium on an increasingly controversial topic: sport hunting of wildlife. But we are talking about more than sport hunting. We are implicitly discussing the need for humans to provide humane stewardship for wildlife both for the sake of wildlife and for the sake of ourselves. One way to begin this is to challenge the killing of wild animals for fun, that is, sport hunting, in America at large and on National Wildlife Refuges.

\section{Hunting in America Today}

Initially, it is important to define the terms that we are discussing, by viewing hunting in the context in which it exists today. In that regard, we must recognize that we are not talking about hunting as it existed for the pilgrims at Plymouth Rock. We are not discussing hunting as it existed in the time of Abraham Lincoln. We are not even discussing hunting as it existed at the turn of the century, or during the Depression. Nor are we discussing a remote sort of "wilderness hunting" that "pits man against beast."

Rather, we must recognize hunting as it exists for most of those hunting in America today. It is a recreational pastime. Sometimes, as in some forms of "waterfowl hunting," it is little more than shooting at animated targets. It is pursuit of big game "trophies." At its best, it is a form of pleasure from which some people derive some meat that is either eaten or discarded. However, hunting today is not necessary in any sense. As a television reporter said to me not long ago, "we're talking about Joe Sixpack." And while that image is not precise, it is very descriptive. Hunting or killing animals is a form of mostly macho, comraderie-based human recreation. In general it is not romantic, it is not meat hunting, it is not necessary. It is a form of fun. The question is whether society will continue to permit and glorify modern day hunting, the killing of mammals and birds for human pleasure, as an acceptable form of fun.

\section{Objections to Sport Hunting}

The objections to sport or recreational hunting are not new. Most basically, hunting inflicts needless undeniable cruelty-pain, suffering, trauma, wounding, and death-on living, sentient creatures. And it does so for nothing more than sport. 
Methods of killing animals are archaic, without even minimal attempts to ensure either a lack of pain and suffering, or a quick, humane kill. Hunters use bow and arrow even though it is well known that the bow and arrow causes orders of magnitude more wounding and suffering than might be caused by another kind of weapon. "Primitive" muskets are used, although they are subject to the same kinds of objections as bow and arrow. Not only do officials continue to allow the use of muskets and bow and arrow, but state Fish and Game agencies across the country have established special seasons so that people interested in using bow and arrow and/or musket will not be interfered with by other hunters (sort of a special season which legitimizes the increased cruelty from these weapons). Finally, hunters use lead shot in shotguns. Lead shot not only kills the animals which get shot, but also causes the death by prolonged, excruciating poisoning of more than three million ducks, geese, swans, doves, and other seed-eating birds each year. This needless destruction continues because the hunting community refuses to use steel shot, in spite of the mass poisoning and despite the fact that steel shot is an effective substitute for lead.

Next we must look at what messages we are leaving for our children, young people, and society. The ethic - if it may be called that - of killing for fun teaches callousness, disrespect for life, and the notion "might makes right." It certainly causes a numbing of sensitivity and empathetic responses to animals, including humans. Are these the kinds of values that a civilized society wants to pass on as its legacy? I hope not.

Sport hunting also has destructive impacts on the animals themselves. Obviously, millions of animals are killed outright. These are animals for whom death is at best a "clean kill," but who often suffer a slow, lingering death that includes wounding, suffering, pain, and fear. Representative numbers are fifteen million dead doves each year, twenty million dead ducks and geese, millions of deer and scores of millions of such animals as squirrels, rabbits, bobwhite quail, prairie grouse, turkey, woodchucks, foxes, bobcats, crows, magpies, and myriad others. Hunting also has other destructive impacts. In big game animals, for example, hunters attempt to kill the largest (and presumably genetically superior) animals from the population. Reportedly, this has had serious impacts in terms of reducing the survivability of herds of bighorn sheep. Similar impacts are likely in deer, elk, and moose. Also, hunting removes from natural systems the animals that other animalspredators and scavengers - utilize for food. Nature wastes nothing. Doves which are not killed for human fun, are food for hawks, owls, falcons, and others. The removal of wildlife by sport hunting deprives ecosystems and their animal inhabitants of food.

And, lastly, there is the ghastly "incidental" toll from sport hunting. Each year hunters across this land in pursuit of what they describe as "good clean fun" shoot cows, sheep, goats, horses, pets, highway signs, homes, and endangered and protected species. And even if this is all accidental or incidental, it is still death and destruction that occurs as a by-product of a 
highly objectionable form of recreation: killing other animals for fun. And, finally, how should society respond to the fact that thousands of people are killed or wounded in sport hunting accidents every year?

Someone is sure to say that many of the problems I have pointed out can be alleviated by "cleaning hunting up." By teaching hunters to identify their targets, by instilling "respect" and "good hunting manners," by eliminating lead shot, or by enacting and enforcing strong regulations. But still, the salient fact is that we are talking about "cleaning up" the killing of animals for fun. That, I submit, is a contradiction in terms: you can not clean up a sport based on inflicting needless pain, suffering, and death to innocent animals.

\section{Objections to Hunting on Refuges}

For the other part of my presentation, the organizers of this symposium requested that I discuss the case against hunting on National Wildlife Refuges. I am, I admit, positively underwhelmed. Having presented in excruciating detail the case against sport hunting in general, it is an insult to our collective sanity to discuss the "merits" of sport hunting on Refuges.

National Wildlife Refuges were set up to be the one "inviolate sanctuary" for wildlife in this nation. That is why they were called refuges. They were to provide safe haven and sanctuary, and that is the public view of their purpose.

Sport hunting programs assault the very concept of "refuge." It is no less than the rape of the refuge system. There are numerous other impacts as well. There are the objections to sport hunting in general which I mentioned earlier. Hunting programs result in the death of half a million refuge animals each year. Hunting scares wildlife, making it hard for people to see animals on refuges. Hunters kill endangered species on refuges. Destroy habitat. Deposit toxic lead shot. Cause suffering, wounding. And... waste public tax dollars on programs that are destructive of the very purpose for which refuges were established. Finally, as if all that were not enough, refuge officials are now conducting predator control programs: that is, killing predators like foxes and raccoons so that hunters can have more ducks to shoot on refuges.

The whole system is an affront to the public as well as wildlife. Hunting simply has no place on National Wildlife Refuges.

\section{Arguments Used in Favor of Hunting}

So with all of that, what, you may ask, are the reasons offered by the hunting community as justification for continuing their sport? First, and most interestingly, is the assertion that hunting is a near-religious - even mysticalexperience, that it brings man closer to nature and to his roots. This argument is exemplified by Dr. William Robinson's paper [see this volume]. In the portion of his paper where he is quoting from a bow hunter's description of the kill, we are implicitly invited to hear and see the very origins of man.

With all due respect to Dr. Robinson, however, such hunting is an anachronism. It is a throwback to a time gone by ... long ... long ago! Dr. Robinson would ask the public to accept sport hunting and killing for fun because a few 
people continue to try to practice hunting as a semi-religious experience. Dr. Robinson, however, can not avoid the salient facts of hunting in America today. It is a recreational pastime that has nothing to do with feeding families and getting people closer to nature. It is a form of recreation that thrives on the killing of innocent beings.

It is also important to note that the move to end sport hunting in America is a part of social evolution that Robinson's arguments deny. Hunting may once have been a mystical experience as Robinson would portray it today. However, as society has grown and matured, the place of hunting and the reasons for hunting have changed. Society now finds itself reevaluating the ethics of sport hunting and the need for it in a civilized twentieth century culture. Robinson's arguments suggest that we should ignore this social evolution and try to return to the days of our forefathers. This is totally unrealistic as well as counterproductive to society's ethical and moral growth.

Aside from Robinson's naturalistic arguments in favor of hunting, Nelson's paper at this symposium [see this volume] alludes to other purportedly modern-day "justifications" for sport hunting. These are arguments concerned with wildlife management, and I would like to examine them for a moment.

Nelson suggests that sport hunting on National Wildlife Refuges is necessary to prevent starvation of wild animals. Let's examine that assertion. First, I certainly agree that an animal killed by sport hunting is prevented from starving to death! However, sport hunting does not in any sense eliminate starvation. Hunters attempt to kill the largest animals, not those animals which are small, weak, or about to starve to death. Moreover, wildlife itself would be the loser if hunting could prevent starvation, because many wild animals (omnivores and carnivores) depend for their food on animals that die of starvation or are weakened by a lack of food

Mr. Nelson also suggests that hunting is generally permitted on Refuges in order to limit growth of wildlife populations. This is simply not true. Indeed, fall hunting for species like whitetailed deer stimulates birth, by tending to make more food available to each deer that remains. No better example of the fact that hunting seasons are not aimed at limiting deer populations can be given than to note that if wildlife managers were truly interested in just limiting populations they would open a season for females only, but they never do. One might also ask: if deer hunting is really just done as a form of benevolent population limitation, would hunters favor other more humane forms of population limitation that would not involve sport hunting? And the answer to that question is almost certainly "No." The facts are, we must keep reminding ourselves, that hunting on National Wildlife Refuges and elsewhere is not being conducted and promoted to limit wildlife populations but rather to provide "fun" for a small percentage of the people. ${ }^{3}$ In fact, Refuge managers have no idea what the population levels of most hunted animals are, much less how much, if any, the population of such animals will be reduced by sport hunting. A representative list of animals hunted in recent years on National Wildlife Refuges includes: 


$\begin{array}{lll}\text { mergansers } & \text { partridge } & \text { badger } \\ \text { blackducks } & \text { grouse } & \text { bobcat } \\ \text { other ducks } & \text { sage grouse } & \text { mountain goat } \\ \text { geese } & \text { scaled quail } & \text { bighorn sheep } \\ \text { rails } & \text { Gambel's quail } & \text { whitetailed deer } \\ \text { crows } & \text { turkey } & \text { black bear } \\ \text { ravens } & \text { willow ptarmigan } & \text { grizzly bear } \\ \text { woodcock } & \text { grey squirrel } & \text { Kodiak bear } \\ \text { snipe } & \text { red fox } & \text { rabbit } \\ \text { doves } & \text { grey fox } & \text { hare } \\ \text { magpies } & \text { arctic fox } & \text { opossum }\end{array}$

Mr. Nelson also suggests that hunting is necessary to keep populations of wild animals healthy, or to free them from disease. However, these assertions are simply wrong. At best for the wildlife populations, the effects of hunting are random. That is to say, animals are killed randomly regardless of health, genetic makeup, age, sex, or experience. Often, I suggest, the effects of sport hunting programs are far worse because hunters shoot the largest, strongest, most genetically superior animals, thereby removing them from the population.

Finally, Mr. Nelson suggests that hunting should be allowed on Refuges because hunters buy duck stamps and duck stamp monies have been used to purchase land for wildlife refuges. First, I will examine the details of $\mathrm{Mr}$. Nelson's assertion. True, some refuge lands have been purchased by duck stamp funds. According to the 1985 Fish and Wildlife Service Realty Survey, a maximum of 2.9 million acres of land (or $3.3 \%$ of the Refuge system) have been purchased with funds derived from duck stamp sales. In contrast, the refuge system contains some 89 million acres of land, nearly all of which has been withdrawn from the public domain or purchased with Land and Water Conservation Fund monies. Thus, if the claims of hunters to hunt on Refuge lands could be said to be legitimately based on purchases of land with duck stamp funds, hunting would be scarce indeed.

And it is important to examine the implications of the Land and Water Conservation Fund purchases as well. The Land and Water Conservation Fund consists of monies derived in large part from the revenues received by the United States government as a result of offshore (continental shelf) oil and gas leases. Funds from the Land and Water Conservation Fund have been used to purchase National Wildlife Refuge lands, city parks, state parks, and a host of other public recreation areas. However, just because the Land and Water Conservation Fund was derived from oil and gas leases does not give the oil and gas industry the right to drill in city parks or on National Wildlife Refuges. By the same token, the fact that some refuge lands have been purchased with duck stamp monies does not confer any implicit or explicit right to hunters to hunt on those lands. Indeed, society might more properly consider revenues from duck stamp purchases as a minimal form of damage payment to society at large for the loss of tens of millions of ducks and 
geese each year. And, I might incidentally note, the time has come for society to evaluate whether such a "bargain" is a good one.

The bottom line about sport hunting is that it is no management tool at all. It is, as I have said repeatedly, a form of human recreation-fun-that brutally sacrifices the life of innocent wild creatures. Moreover, it must be viewed in another way. It is, in fact, a commercial enterprise. Commercial, you say? Someone is bound to mention that this is not commercial hunting; commercial hunting has been outlawed. But it is commercial in two important senses. First, hunting is commercial in that state fish and game agencies receive substantial portions of their salary monies and operating funds by virtue of the sale of hunting licenses. In essence, there is a strong commercial incentive for state fish and game agencies to encourage and promote sport hunting just to stimulate the sale of hunting licenses and resultant income.

And, hunting is a commercial enterprise in another important sense as well. Pick up an issue of Field and Stream, American Rifleman, Outdoor Life, or another outdoor/hunting magazine. Those magazines and the advertisements therein promote the sale of guns and ammunition, outdoor clothing, and other associated products. Readers of these publications are being encouraged to become hunters and buy these products. The message is "be tough, be strong, be in, be a hunter ... buy." Promoting hunting is a way of stimulating increased sales of guns, shoes, wilderness "adventures" and numerous other commercial products.

Thus, in a very real way, two forces in twentieth century America are manipulating people to hunt through slick advertising and promotional programs. The sooner people recognize and reject this manipulation and resultant destruction, the better off both wildlife and the public at large will be.

\section{Conclusion}

Sport hunting has no place on the National Wildlife Refuges of this nation. To even consider it is an affront to the concept of a Refuge, the right of wild animals to safe haven, and the wishes of society. The question of sport hunting in society at large is slightly more complex because society, its thoughts and values, are evolving. Thankfully, we are moving more and more to a view that wildlife should be treated with the same dignity, respect, and freedom from avoidable cruelty that we would ask for ourselves. That process can be moved miles ahead if we eliminate sport hunting — killing for fun - now.

\section{Endnotes}

\footnotetext{
1 Paper presented at the national conference, "Animals and Humans: Ethical Perspectives," Moorhead State University, Moorhead, MN, April 21-23, 1986.

2 Vice President, Wildlife and Environment, The Humane Society of the United States, 2100 L St, NW, Washington, DC 20037.

3 Sport hunting by the public at large is conducted by eight to ten percent of the public; on Refuges, sport hunting is conducted by less than one-half of one percent of the public.
} 